\title{
Assessment of heavy metals in brands of canned fishes stored in vegetable oil marketed in Benin city, Nigeria
}

\author{
Andress Edowaye Odiko \\ Department of Aquaculture and Fisheries Management, University of Benin, Edo state, NIGERIA \\ E-mail: andress.odiko@uniben.edu
}

Received: May 17, 2017; Revised received: July 16, 2017; Accepted: August 28, 2017

Abstract: This study was undertaken to ascertain the safety level of consuming canned fish as it relates to metals. Seven commonly consumed canned fish brands stored in vegetable oil sold in Benin-City were bought from super stores and in the open markets and stored at ambient temperature between January to September, 2015. A total of 106 samples were collected and analysed in triplicates for iron (Fe), zinc ( $\mathrm{Zn})$, manganese (Mn), nickel (Ni) and vanadium (V); which were detected in all the canned fish samples but $\mathrm{V}$ had an average of $0.024 \mathrm{mg} / \mathrm{kg}$ value during the study which was just a detection level. The heavy metal variation ranged between $2.21-21.38 \mathrm{mgFe} / \mathrm{kg}, 5.41-$ $52.35 \mathrm{mgZn} / \mathrm{kg}, 0.05-0.72 \mathrm{mgMn} / \mathrm{kg}, 0.42-7.00 \mathrm{mgNi} / \mathrm{kg}$ and $0.02-0.16 \mathrm{mgV} / \mathrm{kg}$ respectively during the period of study. Generally, heavy metal concentration increased with increasing storage time especially Fe and $\mathrm{Zn}$. There was significant difference in the mean concentration of the heavy metal levels evaluated during the period of study in the different brands $((p>0.05)$. The Laser, Soil and Titus sardines were significantly higher. However, all the metal concentrations were not significantly different $(p>0.05)$ from the permissible set limits by Food and Agriculture Organization (FAO), World Health Organization (WHO) and European Union (EU) legislation for fish except for nickel. Effort must therefore be made to comprehensively and intermittently monitor metal levels on arrival and during long time storage of canned fish. As this will not only help to safeguard the health of the citizenry but the point at which metal contamination occurs can be effectively deduced and appropriate measures could then be taken to prevent metal contamination.

Keywords: Assessment, Canned fish, Metals, Nigeria, Vegetable oil

\section{INTRODUCTION}

Fish is widely consumed in many parts of the world by humans because it has high protein content, low saturated fat and also contains Omega 3 fatty acids known to support good health. Globaly, per capita fish consumption have risen to over $20 \mathrm{~kg} / \mathrm{yr}$ in 2016 , against an average of $9.9 \mathrm{~kg}, 14.4 \mathrm{~kg}$ and $19.7 \mathrm{~kg}$ in 1969 's, 1990's and 2013 respectively (USEPA, 2004; FAO, 2016). Nigeria requires about 3.32 million metric tons for consumption annually based on the 2014 population estimate of 180 million people, producing only 1.1 million metric ton and having to import over 2 million MT of fish and fish products. In 2014 alone it was reported by the department of Fisheries Statistics (2016) that Nigeria imported over 8,000 metric tons of fish and fish products. Fish and other aquatic life forms are found in water that is constantly exposed to chemicals, pollutants and other contaminants. Fish may be contaminated by toxic elements during growth, transportation and storage. Contamination may also occur during production, handling and canning process. Fish have been found to be good indicators of heavy metals contamination in aquatic systems because they occupy different tropic levels and are of different sizes and ages (Goyer, 1994). Food safety demand therefore, being a major public concern worldwide during the last decade, has stimulated researches regarding the risk associated with consumption of foodstuffs contaminated by different classes of contaminants.

Investigation of heavy metals in canned fishes and dietary intakes of toxic elements from canned fishes sold in Edo State Nigeria are limited, it becomes necessary to carry out this study to determine and ascertain the state of heavy metal levels of canned fishes and fish products preserved in the vegetable oil imported and sold in the Nigeria market; particularly in Edo State. This study was therefore undertaken to compare heavy metal contents of the different make of canned fishes and also compare these data with the set safe standard levels set by FAO and WHO, whose standards are adopted presently in Nigeria

\section{MATERIALS AND METHODS}

The study was carried out in Benin City, Edo state, Nigeria, approximately 25miles north of the Benin River. Benin City was established in the $13^{\text {th }}$ century and the city has an estimated population of $1,147,188$ people (Census, 2006). Seven different types of canned fish products samples imported from different coun- 
tries were obtained from retail supermarkets and open market in the State. The analysis of collected samples was done between January - September 2015. Table 1 show the names, storage medium and other information collected and recorded from the label on the can brand samples purchased in SuperStores and open market in Benin City, and used for this study

All reagents used were of analytical grades unless where stated otherwise, and all digestion and analysis were carried out according to AOAC (1995). The experiment was done in triplicates and data obtained were analyzed using computer software (SPSS version 21 ), one way analysis of variance (ANOVA) at significant differences between means at $5 \%$ probability level. Duncan's Multiple Range Test was used to analyze the significant difference between homogenous subsets and the data are reported as mean values \pm standard deviation (Freud et al., 1997).

\section{RESULTS AND DISCUSSION}

The ingestion of seafood is an obvious means of exposure to heavy metals, especially fish because they occupy different trophic levels with different sizes, age, season and habitat (Burger et al., 2002). However, due to advances of new packaging technology especially the use of cans with lacquered walls and mechanical seam, reduces or in most cases eliminates the leaching of heavy metals ( $\mathrm{Fe}, \mathrm{Zn}, \mathrm{Mn}, \mathrm{Ni}$ and $\mathrm{V}$ ) into food. Results from this study showed the occurrence of Fe, $\mathrm{Zn}$, $\mathrm{Mn}, \mathrm{Ni}$ and $\mathrm{V}$ in all seven canned fishes stored in vegetable oil purchased in open markets and supermarkets in Benin-City, Edo State, Nigeria during different months of the year (Table 2).

Iron is an important constituent of hemoglobin, myoglobin and enzymes like xanthine, carbon monoxide hydrogenase among others, estimated daily iron requirements for children $0-10$ years ranges between $1.3 \mathrm{mg}$ and $6.7 \mathrm{mg}$. Estimated daily requirements in the U.K are 8.7 and $6.7 \mathrm{mg}$ for males aged $11-18$ and $19+$ respectively (COMA, 1991). For women aged 11-50, the estimated average daily iron requirement is $11.4 \mathrm{mg}$ while for postmenopausal women is $6.7 \mathrm{mg}$. The FAO/ WHO recommended $\geq 18 \mathrm{mg} /$ day for women during their reproductive life. Iron content observed during this study and that obtained during similar study by Iwuoha et al. (2013) in Rivers state, Nigeria;were similar. The daily FAO/WHO recommended requirement was only exceeded by Laser sardines $(21.38 \mathrm{mg}$ / $\mathrm{kg}$ ) (Table 3).

Zinc is widespread among living organisms, due to its biological significance and has been implicated in most metabolic pathways in humans; its deficiency can lead to loss of appetite, growth retardation, skin changes and immunological abnormalities. The maximum zinc level permitted for fish is $50 \mathrm{mg} / \mathrm{kg}$ according to Food Codex (MAFF, 1993), this value is lower than those obtained from this work whose maximum was $52.35 \mathrm{mg} / \mathrm{kg}$ in Laser sardines. However, zinc content of Soil sardines and Titus sardines exceeded the U.K required nutritional intake (RNI) ranges set by COMA for zinc of $5.5-9.5 \mathrm{mg} / \mathrm{kg} / \mathrm{day}$. According to Celik and Oehlenschlager (2006), the highest zinc concentration in Turkish canned fish samples was $33.8 \mathrm{mg} /$ $\mathrm{kg}$ but work done by Mendil et al. (2005) in Lake Tokat Turkey gave level of zinc as $48.6 \mathrm{mg} / \mathrm{g}$. The results from these findings are in agreement with other findings where $34.0 \mathrm{mg} / \mathrm{kg}$ have been observed in canned anchovy and $7.5 \mathrm{mg} / \mathrm{kg}$ in canned sardine (Tuzen, 2009). Amount higher than the tolerable limit of zinc may result in decreased absorption of dietary carbohydrate and induce apoptosis in the cell line according to Sensil et al. (2009). As intercellular zinc has been shown to accumulatein different tissues and cell type as either as a consequences of exogenous administration or release from intracellular stores by reactive oxygen species or nitrosation that could lead to induced cell death by inhibition of the energy metabolism (Tyszka et al., 2014).

The mean monthly concentration of Mn during this study was $0.27 \mathrm{mg} / \mathrm{kg}$ and was below the recommended value of $1-10 \mathrm{mgMn} /$ person/day and $0.3-1,1-3$ and 2$5 \mathrm{mgMn} /$ day for infants, children and adults respectively by the EU Scientific Committee for food (EU$\mathrm{SCF}$ ) and the US National Research Council (NRC). However, Titus sardine, Laser sardine and Soil sardine can be said to meet the Mn requirement for infants. Manganese concentration range of $0.05 \mathrm{mg} / \mathrm{kg}$ to $0.09 \mathrm{mg} / \mathrm{kg}$ obtained in this study is below the corresponding maximum level reported for canned sardines in Brazil which was $15.77 \mathrm{mg} /$ day (Tarley et al., 2001). Daily intake of $2 \mathrm{mg}$ Manganese is essential for growth and good health in children as children as well as adults, who lose the ability to remove excess manganese from their bodies, develop nervous system problems, although there are no information on the carcinogenicity of manganese according to EPA (ATSDR, 2004). It should be known that manganese levels in foods may also be affected by method of processing.

All analyzed canned fish samples had high concentration levels of nickel, which has been implicated in respiratory problems when high amounts accumulate in the lungs causing bronchial failure. It acts as an activator of some enzyme systems but its toxicity at higher levels is of great concern (ATSDR, 2004).

Result obtained from this study for vanadium was lower than that obtained by Ikem and Egiebor (2005) with values of $\mathrm{V}$ ranging between $0.0-0.31 \mathrm{mg} / \mathrm{kg}$. The upper tolerable intake level of vanadium for adults (19 -70years) is $1.8 \mathrm{mg} /$ day and there are no data available for other age groups (Institute of Medicine, 2003).

This study has shown that all the analyzed metals were present in all the canned fishes at varied concentrations although $\mathrm{V}$ was almost below detection level. Considerable differences were found in the levels of these 
Table 1. Record of different canned fish product used for study.

\begin{tabular}{|c|c|c|c|c|c|c|}
\hline Brand name & $\begin{array}{l}\text { Storage me- } \\
\text { dium }\end{array}$ & $\begin{array}{l}\text { Weight } \\
\text { (g) }\end{array}$ & $\begin{array}{l}\text { Fish species } \\
\text { canned }\end{array}$ & $\begin{array}{l}\text { Common name } \\
\text { of fish used }\end{array}$ & $\begin{array}{l}\text { Manufacturing } \\
\text { country }\end{array}$ & $\begin{array}{l}\text { Expiring } \\
\text { date of } \\
\text { products }\end{array}$ \\
\hline Napa Valley & Vegetable oil & 170 & Flake tuna & Albacore tuna & Thailand & $07 / 2017$ \\
\hline Laser & Vegetable oil & 125 & Sardine & $\begin{array}{l}\text { Albacore white } \\
\text { tuna }\end{array}$ & Morocco & $06 / 2017$ \\
\hline Founty & Vegetable oil & 125 & Sardine & $\begin{array}{l}\text { South African } \\
\text { sardine }\end{array}$ & Morocco & $12 / 2017$ \\
\hline Titus & Vegetable oil & 125 & Sardine & True sardine & Morocco & $06 / 2017$ \\
\hline Geisha & Vegetable oil & 125 & Sardine & $\begin{array}{l}\text { South African } \\
\text { sardine }\end{array}$ & China & $07 / 2017$ \\
\hline $\begin{array}{l}\text { Soil sardine } \\
\text { Costa }\end{array}$ & Vegetable oil & 125 & Sardine & True sardine & China & $09 / 2017$ \\
\hline
\end{tabular}

Table 2. Concentrations of the metals of products stored in vegetable oil within the months of January - September 2015, Benin City Nigeria.

\begin{tabular}{lccccc}
\hline \multirow{2}{*}{ Month } & \multicolumn{5}{c}{ Metals $(\mathbf{m g} / \mathbf{k g})$} \\
\cline { 2 - 6 } January & $\mathbf{F e}$ & $\mathbf{Z n}$ & $\mathbf{M n}$ & $\mathbf{N i}$ & $\mathbf{V}$ \\
March & $6.30 \pm 1.45^{\mathrm{d}}$ & $17.14 \pm 3.95^{\mathrm{c}}$ & $0.19 \pm 0.05^{\mathrm{c}}$ & $1.52 \pm 0.43^{\mathrm{c}}$ & $0.05 \pm 0.01^{\mathrm{c}}$ \\
May & $7.10 \pm 1.64^{\mathrm{bcd}}$ & $19.31 \pm 4.45^{\mathrm{bc}}$ & $0.22 \pm 0.05^{\mathrm{bc}}$ & $1.71 \pm 0.49^{\mathrm{bc}}$ & $0.06 \pm 0.01^{\mathrm{bc}}$ \\
July & $8.52 \pm 1.96^{\mathrm{bc}}$ & $19.31 \pm 4.45^{\mathrm{bc}}$ & $0.26 \pm 0.06^{\mathrm{bc}}$ & $2.05 \pm 0.58 \mathrm{bc}$ & $0.07 \pm 0.01^{\mathrm{b}}$ \\
September & $8.89 \pm 2.05^{\mathrm{b}}$ & $23.17 \pm 5.34^{\mathrm{ab}}$ & $0.27 \pm 0.07^{\mathrm{b}}$ & $2.14 \pm 0.61^{\mathrm{b}}$ & $0.07 \pm 0.01^{\mathrm{b}}$ \\
\hline
\end{tabular}

Means within the same column having different superscripts are significantly different $(\mathrm{P}<0.05)$.

Table 3. Mean values of selected metals $(\mu \mathrm{g} / \mathrm{g})$ in different brands of cannedfish between January - September 2015, Benin City Nigeria.

\begin{tabular}{lccccc}
\hline & \multicolumn{5}{c}{ Metals (mg/kg) } \\
\cline { 2 - 6 } Canned Fish & $\mathbf{F e}$ & $\mathbf{Z n}$ & $\mathbf{M n}$ & $\mathbf{N i}$ & $\mathbf{V}$ \\
\hline Founty Sardine & $2.21 \pm 0.13^{\mathrm{e}}$ & $5.41 \pm 0.22^{\mathrm{e}}$ & $0.05 \pm 0.00^{\mathrm{c}}$ & $0.42 \pm 0.02^{\mathrm{f}}$ & $0.03 \pm 0.02^{\mathrm{de}}$ \\
Laser Sardine & $21.38 \pm 1.24^{\mathrm{a}}$ & $52.35 \pm 2.09^{\mathrm{a}}$ & $0.49 \pm 0.03^{\mathrm{b}}$ & $7.00 \pm 0.41^{\mathrm{a}}$ & $0.16 \pm 0.01^{\mathrm{a}}$ \\
Geisha Sardine & $2.34 \pm 0.14^{\mathrm{e}}$ & $5.73 \pm 0.23^{\mathrm{e}}$ & $0.09 \pm 0.00^{\mathrm{c}}$ & $0.45 \pm 0.03^{\mathrm{f}}$ & $0.03 \pm 0.00^{\mathrm{de}}$ \\
Soil Sardine & $12.58 \pm 0.74^{\mathrm{c}}$ & $30.80 \pm 1.26^{\mathrm{c}}$ & $0.72 \pm 0.04^{\mathrm{a}}$ & $2.40 \pm 0.14^{\mathrm{c}}$ & $0.09 \pm 0.04^{\mathrm{c}}$ \\
Costa Sardine & $3.08 \pm 0.18^{\mathrm{d}}$ & $7.53 \pm 0.30^{\mathrm{d}}$ & $0.07 \pm 0.00^{\mathrm{c}}$ & $0.59 \pm 0.03^{\mathrm{de}}$ & $0.04 \pm 0.00^{\mathrm{d}}$ \\
Titus Sardine & $17.00 \pm 1.02^{\mathrm{b}}$ & $41.62 \pm 1.79^{\mathrm{b}}$ & $0.39 \pm 0.02^{\mathrm{b}}$ & $3.24 \pm 0.19^{\mathrm{b}}$ & $0.12 \pm 0.00^{\mathrm{b}}$ \\
Tuna Flakes & $2.35 \pm 0.14^{\mathrm{e}}$ & $5.75 \pm 0.23^{\mathrm{e}}$ & $0.05 \pm 0.00^{\mathrm{c}}$ & $0.60 \pm 0.03^{\mathrm{d}}$ & $0.02 \pm 0.00^{\mathrm{e}}$ \\
\hline
\end{tabular}

Means within the same column having different superscripts are significantly different $(\mathrm{P}<0.05)$.

metals among the different brands but were in compliance with the recommended standards set by FAO, WHO and EU legislation for fish and fishery products except the concentration of zinc in Laser sardines which was above $50 \mathrm{mg} / \mathrm{kg}$ set limit (Table 3). Nickel concentration was above the permissible limit set by FAO, WHO and EU legislation as this metal if not having carcinogenic effect could lead to respiratory problems. Exposure to metals by fish is mainly through their food intake and by absorption from the water column. Laser sardine was observed to have the highest concentration of these metals but it was lowest in Founty sardine, Giesha sardines and Napa valley

\section{tuna flakes.}

\section{Conclusion}

These canned fish samples now considered relatively safe for consumption, over prolonged consumption period could become unsafe and could lead to chronic accumulation of metals in the kidney and liver of humans causing disruption of numerous biochemical processes, as fish consumption is not meant to act as a supplement.Therefore, too frequent consumption of canned fish should be discouraged as this may result in bioaccumulation of the metals and increase health risks. More research and assessments of seafood qual- 
ity is needed in Nigeria to make available data that will help safeguard the health of the populace.The countries of production should enact and enforce laws that will monitor production chain; prevent the dumping of untreated domestic and industrial effluents into the aquatic environment.

\section{REFERENCES}

ATSDR (2004). Agency for Toxic Substances and Disease Registry, Division of Toxicology, Clifton Road, NE, Atlanta, GA, available at: http:// www.atsdr.cdc.gov/toxprofiles.

AOAC (1995). Association of Official Analytical Chemists Official methods of analysis of AOAC international (16 ${ }^{\text {th }}$ edn), Washington DC, USA.

Burger, J., Gaines K. F., Shane B. C., Stephens W. L., Snod grass J., Dixon C., McMahon M., Shukla T. and Gochfeld M. (2002). Metal levels in fish from the

Savannah river: potential hazards to fish and other receptors. Environmental Research, 89-85.

Celik, U. and Oehlenschlager, J. (2006). High contents of cadmium, lead, zinc and copper in popular fishery products sold in Turkish supermarkets. Food Control, 18 (3):258-261

Census (2006). National population commission Abuja, Nigeria National Census, 2006.

COMA, (1991). Committee on Medical Aspects of Food and Nutrition Policy: Dietary Reference Values for Food Energy and Nutrients for the UK. HMSO, London.

FAO (2016). State of the World Fisheries and Aquaculture. Contributing to food security and nutrition for all. Rome 200pp.

Freud, R. J. and Wilson, W. J. (1997). Design of experiments. San Diego (CA), Academic Press. 464pp

Goyer, R. A. (1994). Biology and nutrition of essential elements. In: Risk Assessment of Essential Elements, ed. W Mertz, CO Abernathy, SS Olin, pp. 13-19.Washington, DC: Int. Life Sci. Inst. 300 pp.

Ikem, A. and Egiebor, N. O. (2005). Assessment of trace elements in canned fishes (mackerel, tuna, salmon, sardines and herrings) marketed in Georgia and Alabama (United States of America). Journal of Food Composition and Analysis. 18: 771-787.
Institute of Medicine (2003). Dietary Reference Intakes: Applications in Dietary Planning. Subcommittee on Interpretation and Uses of Dietary Reference Intakes and the Standing Committee on the Scientific Evaluation of Dietary Reference Intakes. Institute of Medicine of the National Academies, The National Academies Press, Washington, DC, p. 248.

Iwuoha, G. N., Uporo, V. B and Onwuachu, U. I. (2013). Variation of Heavy metals in Canned Giesha and Founty Mackerel Fish Brands Obtained from Choba Market Port Harcourt, Nigeria. Journal of Applied Science Environmental Management.17(4): 577-580

MAFF (1993). Monitoring and surveillance of nonradioactive contaminants in the aquatic environment and activities regulating the disposal of wastes at sea. Ministry of Agriculture Fisheries and Food, Aquatic Environment Monitoring Report No. 44. Directorate of Fisheries Research, Lowestoft.

Mendil, D., Uluoylu, O. D., Hasdemir, E., Tuzen, M., Sari, H. and Suicmez, M. (2005). Determination of trace metal levels in seven species in lakes in Tokat, Turkey. Food Chemistry. 90: 175-179.

Sensil, S. L., Paoletti, P., Bush, A. I. and Sekler, I. (2009). Zinc in the physiology and pathology of the central nervous system. Nat. Rev. Neurosci. 10(11): 780-791

Tarley, C. R. T., Coltro, W. K. T., Matsushita, M. and de Souza, N.E. (2001). Characteristic levels of some heavy metals from Brazilian canned sardines (Sardinella brasilliensis). Journal of Food Composition and Analysis 14:611-617.

Tuzen, M. (2009). Toxic and essential trace elemental contents in fish species from the Black Sea, Turkey. Food and Chemical Toxicology, 47: 1785-1790.

Tyszka - Czochara, M., Grzywacz, A., Gdula-Argasinska, J., Librowski, T., Wilinski, B. and Opoka, W. (2014). The role of zinc in the pathogenesis and treatment of central nervous system (CNS) disease. Implications of zinc of homeostatis for proper CNS function. Acta Pol Pharm. 71(3): 369-377.

USEPA (2004). What you need to know about mercury in fish and shellfish. United States Environmental Protection Agency, EPA-823-F-04-009, 2pp, available at: http://www.epa.gov/ waterscience/fish/ Methylmercury Brochure.pdf. 